\title{
The Development of a Code of Practice and Indicators for Official Statistics Quality Management in Thailand
}

\author{
Titirut Mekbunditkul ${ }^{\star}$ \\ Dhurakit Pundit University \\ titirut.thi@dpu.ac.th
}

\begin{abstract}
This research was granted by the National Statistical Office of Thailand and it aims to construct Code of Practice and indicators for official statistics quality management in Thailand. Researcher has studied official statistics quality management from 3 international agencies, such as The United Nations Statistics Division (UNSD), European Statistical System (Eurostat), and International Monetary Fund (IMF). Factor analysis has been used to find the important indicators and their weightings. Findings of this research show the Code of Practice for the official statistics quality management in Thailand should be composed of 9 principles, with 35 indicators.
\end{abstract}

Keywords: Code of Practice, Official Statistics, Quality Management.

\section{Introduction}

International organizations, as well as many countries, have official statistical management standards, depending on the context of that country and international organization. In Europe, for example, international organizations that have a large official statistical management system covering many countries, such as the United Nations Statistics Division (UNSD), whose mission is to assist national statistic development, require a National Statistical system for all members that can support the accurate and reliable production of official statistics. These can then be used for developing the country.

The standard or principle used by the UNSD in producing Official Statistics are based on The Conference of European Statisticians, which developed and adopted the Fundamental Principles of Official Statistics, in 1991, where they agreed to jointly develop a Fundamental Principles of Official Statistics which was to be implemented in 1992. Later, statisticians from all over the world recognized the importance of the fundamental principles and, in 1994, the UNSD declared the acceptance of the fundamental principles with minor adjustments to the introduction and announced the principles under the name of The United Nations Fundamental Principles of Official Statistics. At present, the UNSD is using a generic framework for quality assurance called "The Generic National Quality Assurance Framework (NQAF)" [1] , which many international quality assessment organizations or other countries have been using widely.

Eurostat [2] is the office that prepares and provides statistical data of the European Union, with very high quality statistics, whereby quality assurance has been included as a normal process in the preparation of official statistics. It is not the only agency to prepare statistics and, because international statistics among the European Union must be reliable and comparable, a European Statistical Systems (ESS) [3] was established to ensure standardization among EU countries. All items for statistical collection will have the same standards, from data collection, computation, as well as dissemination. The focus was formerly on the conformity of statistical data within EU policy and afterwards, on other statistical agencies. Later in 2005, the European Statistical System Committee (ESSC) prepared 15 codes of practice to determine standards for the production of official statistics of member countries to have the same standards as the EU.

The International Monetary Fund (or IMF) was established in 1947 by governments of the alliances countries, and is a specialized agency of the United Nations with a regulation requiring that any member of the World Bank must also be a member of the IMF. Members of the IMF must already 
be a member of the UN. At present, there are 188 members, with South Sudan as the $188^{\text {th }}$ member, joining on 18 April 2012. Therefore, producing quality assured statistics requires the combined standards from members, such as the UNSD and ESS. The IMF has used the Data Quality Assessment Framework (DQAF) [4] to assess the quality of the data and to monitor the system and process, whereby the IMF emphasizes statistical results must have the required quality.

In general, each country in the world has their own statistical office. However, developed countries often have a good official statistics system and management that will finally lead to standardized official statistics and quality. Therefore, in 2015, the National Statistics Office asked the researcher to prepare a statistics management system and establish a code of conduct to manage Thailand's official statistics.

As discussed above, the tools used for successful management of quality assurances in each country should comprise a Code of Practice with general indicators, a Quality Assurance Framework, QAF that specifies details for implementation at the level of the institution and the level of survey/product of official statistics. The indicators should be used to build a Quality Model and should conform to the Generic Statistical Business Process Model (version 4.0) (GSBPM).

In the next section, the background of official statistics management system and the Quality Assurance Framework for quality assurance management of international organizations is described.

\section{Background of the official statistics management system and the Quality Assurance Framework for quality assurance management of international organizations.}

Many national and international organizations use an official statistics management system in quality assurance of its official statistics. There are organizations with complete and clear-cut official statistics management system, while other organizations have partial official statistics management in certain processes. The study focuses on 3 organizations that have internationally accepted official statistics management: United Nations Statistics Division (UNSD), Eurostat, and International Monetary Fund (IMF).

\subsection{United Nations Statistics Division (UNSD)}

UNSD has developed a quality assessment framework called NQAF [1] that covers the whole process of official statistics management such as official statistics management, organizational environment, production process, and 19 quality dimensions of official statistics production, specifying in detail the indicators of each dimensions to achieve the quality assurance required by the UN.

The 19 quality dimensions are as follows:

Managing the statistical system: 1) Coordinating the national statistics system, 2) Managing relationships with data users and data providers, 3) Managing statistical standards;

Managing the institutional environment: 4) Assuring professional independence, 5) Assuring impartiality and objectivity, 6) Assuring transparency, 7) Assuring statistical confidentiality and security, 8) Assuring the quality commitment, 9) Assuring adequacy of resources;

Managing Statistical processes: 10) Assuring methodological soundness, 11) Assuring cost-effectiveness, 12) Assuring soundness of implementation, 13) Managing the respondent burden;

Managing statistical outputs: 14) Assuring relevance, 15) Assuring accuracy and reliability, 16) Assuring timeliness and punctuality, 17) Assuring accessibility and clarity, 18) Assuring coherence and comparability and 19) Managing metadata.

From 2010, a template from NQAF was developed, showing indicators in detail, covering all dimensions and processes so that organizations can apply the indicators or use them as framework for quality assurances. However, it is not meant to replace or change the framework of existing quality assurances of statistical offices in each country as each nation needs. There are differences in the adaptation of the NQAF Template, depending on the development, existing resources, institution environment and the concern for the quality of the production of official statistics at 
present. Therefore, the national statistics offices of each country do not need to apply all the NQAF indicators.

\subsection{Eurostat}

Eurostat has developed 15 Codes of Practice [2,3] to create a system for the whole process of official statistic management. It has focused on 4 main issues as NQAF. The code of practice specifies key principles in order to produce quality of official data as required according to EU standard.

The 15 Codes of Practice are:

Institutional Environment: 1) Professional Independence, 2) Mandate for data collection, 3) Adequacy of resources, 4) Commitment to quality, 5) Statistical confidentiality, 6) Impartiality and objectivity;

Statistical Process: 7) Sound methodology, 8) Appropriate statistical procedures, 9) Non-excessive burden on respondents, 10) Cost effectiveness;

Statistical Output: 11) Relevance, 12) Accuracy and reliability, 13) Timeliness and punctuality, 14) Coherence and comparability, and 15) Accessibility and clarity.

A Eurostat Quality Assurance Framework (QAF) has also been established that specifies methods at institutional level and/or product/survey level for each of the key principle for actual implementation, which covers principles 4 and 7 to 15 .

Due to Eurostat emphasizing data utilization, therefore, the result of official statistics must have quality in order that users can have confidence in its correction and appropriation.

\subsection{International Monetary Fund}

IMF has developed a data quality assessment tool called DQAF [4] as a framework for assessing the quality of official statistics data management as a whole process, starting from governance, work system, official statistics production process, as well as the official statistics results, in accordance with IMF role that seek to assess the quality of official statistics production of member countries. IMF has also determined a framework in assessing the whole official statistics production process such as collection, computation, as well as distribution. The DQAF quality assessment framework is internationally accepted, and is used as a basis to develop quality data assessment in several countries.

DQAF comprises two main parts: Prerequisites that organizations should have in order to prepare quality statistics and Quality dimensions.

Prerequisites that organizations should have: Dimension 0.1 Legal and institutional environment; Dimension 0.2 Resources; Dimension 0.3 Relevance; Dimension 0.4 Other Quality Management.

Quality Dimensions. Dimension 1.1 Transparency and Ethical standards; Dimension 1.2 Methodological soundness; Dimension 1.2 Accuracy and reliability; Dimesion1.4 Serviceability; Dimension1.5 Accessibility.

In each quality dimension, there are 3-5 sub-elements, and in each element, there are required indicators. DQAF is thus a general framework that can be applied to all types of data.

\section{Process for establishing a Code of Practice, Thailand Official Statistics Quality Assurance Management and determining format of quality statistical items.}

\subsection{Establishing a Code of Practice}

Quality assurance of Thailand official statistics should follow these steps:

1) Study the Code of Practice for quality management of official statistics of national or international agencies.

2) Call a meeting and jointly determine Code of Practice and indicators of the code of practice for official statistic quality management in Thailand.

3) Draft of the Code of Practice and indicators of Code of Practice of official statistic quality management in Thailand that conforms with 2). 
4) Organize a brain storming session from target group or stake holders to collect the opinion about the Code of Practice and indicators of Code of Practice of official statistic quality management in Thailand.

5) Review and improve the Code of Practice and indicators of Code of Practice of official statistic quality management in Thailand according to the recommendations of target groups and stakeholders.

6) Submit the draft of the Code of Practice and indicators of Code of Practice of official statistic quality management in Thailand to the Subcommittee on Statistical Standards and Academic advisors for comments.

7) Improve the Code of Practice and indicators of Code of Practice of official statistic quality management in Thailand according to the recommendation of the committee/Subcommittee.

\subsection{Process for creating a format for quality official statistics item is as follows:}

1) Use quality indicators of official statistics item of the code of practice to draw up a questionnaire about weighting/loading of the quality of official statistics items, classified by the source of official statistics, such as indicators of official statistics items from surveys, information from administrative data source, and data from combined sources. These will be used in a questionnaire to survey opinions of personnel of the National Statistics Office of Thailand as the agency concerned in providing statistical data and information to users from all sectors.

2) Collect data about all quality indicators of official statistics using the questionnaire concerning the quality of official statistics in general given to the National Statistics Office personnel and the subcommittee of each statistical branch as 94 persons for the whole country.

3) Analyze data collected from the National Statistics Office personnel and the subcommittee of each statistical branch by using factor analysis and determine factors using principle component analysis, classified by source of the official statistics items. This will be used to create a self-evaluation for official statistics for the 21 branches of statistics producers agencies, to build criteria indicators for quality assurance of official statistics, and to create a quality format of official statistics for Thailand.

\section{Results of the study}

\subsection{Code of Practice: The Code of Practice has 9 principles for the quality management in production of official statistics in Thailand}

From an analysis of quality assurance management, Code of Practice, and Data Quality Framework of national and international organizations that are proven tools that can successfully assist Thailand to achieve its quality assurance management of official statistics, the paper has considered international standards for application that should be also appropriate for Thailand's context. Another factor is the requirement of experts who are well experienced in the Thai official statistics system.

As for the Thai context, elements of official statistics production that must be considered are: personnel potential, adequate budget and technology, and value/worthiness of quality assurance of official statistics. Another important factor is the cooperation of all nationwide agencies involved in producing official statistics. The Code of Practice should also determine a small number of "general" indicators so as to encourage cooperation of concerned official statistics production agencies to undertake self-evaluation, and should be adequate to measure quality of Thailand official statistics. The Code of practice for quality management of Thailand official statistics production comprises the following 9 quality dimensions [5]: 
Table1. The Code of Practice - Nine Principles for quality management of Thailand official statistics production

\section{The institutional environment}

Principle 1. Professional and Independence

Principle 2. Statistical Confidentiality

\section{Statistical processes}

Principle 3. Sound Methodology

Principle 4. Appropriate Statistical Procedures

\section{Statistical Output}

Principle 5. Relevance

Principle 6. Accuracy and Reliability

Principle 7. Timely and Punctuality

Principle 8. Coherence and Comparability

Principle 9. Accessibility and Clarity

The indicators of the Code of Practice are listed in Table 1.

\subsection{The quality format of official statistics items classified by the source of official statistic items}

The quality format of official statistics items are drawn from the indicators of official statistics items and the weighting/loading of each indicator, that best describes the quality of the official statistics item.

The quality indicators of official statistics can be determined as a general indicators that can be used for all sources of official statistics where it was obtained, that is, indicators from surveys, data from administrative data source and combination of data source.

From Table 2, the indicators groups of official statistics comprise a total of 35 indicators. The weighting/loading of each indicator would depend on the weight value and percentage of the weighting/loading of each indicator when compared with the weighting/loading of total indicators of each source of the official statistics.

\section{Summary of study and recommendations}

From the study, the Code of Practice - 9 principles for quality management in production of official statistics in Thailand are:

The institutional environment, Principle1. Professional and Independence; Principle2 . Statistical Confidentiality:

Statistical processes Principle3.Sound Methodology; Principle4.Appropriate Statistical Procedures: Statistical Output Principle5. Relevance; Principle 6. Accuracy and Reliability; Principle7. Timely and Punctuality; Principle8. Coherence and Comparability; Principle9. Accessibility and Clarity The weighting/loading of the indicators of the Code of Practice is shown in Table 2 and are used as weights in the calculation of the score of quality of official statistics. 
Table2. Weighting and percentage of weighting of total quality indicators of official statistics items

\begin{tabular}{|c|c|c|c|c|c|c|c|}
\hline \multirow{3}{*}{\multicolumn{2}{|c|}{ Quality indicators of official statistics }} & \multicolumn{6}{|c|}{$\begin{array}{l}\text { Weighting/loading of official statistics quality } \\
\text { indicators }\end{array}$} \\
\hline & & \multicolumn{2}{|c|}{ Survey data } & \multicolumn{2}{|c|}{$\begin{array}{c}\text { Administrative } \\
\text { data }\end{array}$} & \multicolumn{2}{|c|}{$\begin{array}{c}\text { Combination of } \\
\text { data source }\end{array}$} \\
\hline & & Weight & $\begin{array}{c}\text { Percent } \\
\text { age }\end{array}$ & Weight & $\begin{array}{c}\text { Percent } \\
\text { age }\end{array}$ & Weight & $\begin{array}{c}\text { Percent } \\
\text { age }\end{array}$ \\
\hline \multirow{5}{*}{$\begin{array}{l}\overrightarrow{0} \\
\frac{0}{2} \\
:\end{array}$} & $\begin{array}{l}\text { 1.1 Possesses an official statistics unit directly } \\
\text { responsible for producing official statistics }\end{array}$ & 0.6510 & 2.11 & 0.6429 & 2.24 & 0.6457 & 2.25 \\
\hline & $\begin{array}{l}1.2 \text { The official statistics unit has good relations with } \\
\text { other official statistics units and users of official } \\
\text { statistics. }\end{array}$ & 0.6844 & 2.21 & 0.6840 & 2.38 & 0.6873 & 2.39 \\
\hline & $\begin{array}{l}\text { 1.3 The official statistics unit is independent in its } \\
\text { production, development and distribution of data. }\end{array}$ & 0.5290 & 1.71 & 0.5268 & 1.84 & 0.5154 & 1.79 \\
\hline & $\begin{array}{l}\text { 1.4 Personnel of the official statistics unit possess } \\
\text { knowledge and expertise in the process of official } \\
\text { statistics production and can utilize the official } \\
\text { statistics well. }\end{array}$ & 0.6698 & 2.17 & 0.6597 & 2.30 & 0.6568 & 2.29 \\
\hline & $\begin{array}{l}1.5 \text { The official statistics unit has moral or } \\
\text { professional ethics in producing statistical data and } \\
\text { information. }\end{array}$ & 0.6910 & 2.23 & 0.6857 & 2.39 & 0.6758 & 2.35 \\
\hline \multirow{4}{*}{$\frac{2}{0}$} & $\begin{array}{l}2.1 \text { The official statistics unit has criteria for } \\
\text { confidentiality. }\end{array}$ & 0.6592 & 2.13 & 0.6619 & 2.31 & 0.6548 & 2.28 \\
\hline & $\begin{array}{l}2.2 \text { The official statistics unit does not reveal } \\
\text { personal or agency information to the public. }\end{array}$ & 0.6368 & 2.06 & 0.6353 & 2.21 & 0.6282 & 2.19 \\
\hline & $\begin{array}{l}2.3 \text { The official statistics unit possess regulation to } \\
\text { punish personnel who breach the confidentiality } \\
\text { protocol. }\end{array}$ & 0.6323 & 2.05 & 0.6444 & 2.25 & 0.6376 & 2.22 \\
\hline & $\begin{array}{l}2.4 \text { The official statistics unit has a computerized } \\
\text { security system. }\end{array}$ & 0.7037 & 2.28 & 0.7163 & 2.50 & 0.7083 & 2.47 \\
\hline \multirow{6}{*}{$\begin{array}{l}0 \\
\frac{0}{2} \\
\frac{0}{0} \\
\vdots \\
0\end{array}$} & $\begin{array}{l}\text { 3.1 Production of official statistics relies on } \\
\text { international statistical standards and is comparable } \\
\text { nationally and internationally. }\end{array}$ & 0.6915 & 2.24 & 0.6883 & 2.40 & 0.6940 & 2.42 \\
\hline & $\begin{array}{l}3.2 \text { Definitions and scope were established in the } \\
\text { production of official statistics, }\end{array}$ & 0.5140 & 1.66 & 0.5087 & 1.77 & 0.5182 & 1.80 \\
\hline & $\begin{array}{l}3.3 \text { Throughout the process, proper and appropriate } \\
\text { statistical methods were used in the production of } \\
\text { official statistics. }\end{array}$ & 0.6690 & 2.16 & 0.6514 & 2.27 & 0.6553 & 2.28 \\
\hline & $\begin{array}{l}\text { 3.4 Appropriate tools were used to produce and } \\
\text { disseminate official statistics. }\end{array}$ & 0.6102 & 1.97 & 0.6029 & 2.10 & 0.6098 & 2.12 \\
\hline & $\begin{array}{l}3.5 \text { Regular training was provided to continually } \\
\text { improve personnel development. }\end{array}$ & 0.6050 & 1.96 & 0.6126 & 2.14 & 0.6066 & 2.11 \\
\hline & $\begin{array}{l}\text { 3.6 There is coordination with national and } \\
\text { international statistics standard agencies. }\end{array}$ & 0.7167 & 2.32 & 0.7106 & 2.48 & 0.7187 & 2.50 \\
\hline \multirow{2}{*}{ 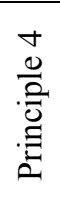 } & $\begin{array}{l}\text { 4.1 Missing data has been compensated through } \\
\text { standardized statistical methods. }\end{array}$ & 0.7385 & 2.39 & 0.7345 & 2.56 & 0.7359 & 2.56 \\
\hline & $\begin{array}{l}\text { 4.2 Recommendations or explanation or manual for } \\
\text { the production of official statistics production was } \\
\text { provided. }\end{array}$ & 0.5652 & 1.83 & 0.5518 & 1.92 & 0.5642 & 1.96 \\
\hline \multirow{3}{*}{$\begin{array}{l}n \\
\frac{0}{2} \\
\frac{0}{0} \\
\vdots \\
0\end{array}$} & $\begin{array}{l}5.1 \text { Official statistics produced fulfill the needs of } \\
\text { target service group. }\end{array}$ & 0.6584 & 2.13 & 0.6696 & 2.33 & 0.6670 & 2.32 \\
\hline & $\begin{array}{l}5.2 \text { Official statistics produced directly answers the } \\
\text { need of target service group. }\end{array}$ & 0.7002 & 2.26 & 0.7074 & 2.47 & 0.6988 & 2.43 \\
\hline & $\begin{array}{l}5.3 \text { Official statistics produced can be used for } \\
\text { decision making, problem solving, planning or } \\
\text { determining policies or application for academic use. }\end{array}$ & 0.7730 & 2.50 & 0.7692 & 2.68 & 0.7624 & 2.65 \\
\hline
\end{tabular}


Table2 (cont). Weighting and percentage of weighting of total quality indicators of official statistics items

\begin{tabular}{|c|c|c|c|c|c|c|c|}
\hline \multirow{3}{*}{\multicolumn{2}{|c|}{ Quality indicators of official statistics }} & \multicolumn{6}{|c|}{$\begin{array}{l}\text { Weighting/loading of official statistics quality } \\
\text { indicators }\end{array}$} \\
\hline & & \multicolumn{2}{|c|}{ Survey data } & \multicolumn{2}{|c|}{$\begin{array}{c}\text { Administrative } \\
\text { data }\end{array}$} & \multicolumn{2}{|c|}{$\begin{array}{c}\text { Combination of } \\
\text { data source }\end{array}$} \\
\hline & & Weight & $\begin{array}{c}\text { Percent } \\
\text { age }\end{array}$ & Weight & $\begin{array}{c}\text { Percent } \\
\text { age }\end{array}$ & Weight & $\begin{array}{c}\text { Percent } \\
\text { age }\end{array}$ \\
\hline \multirow{7}{*}{ 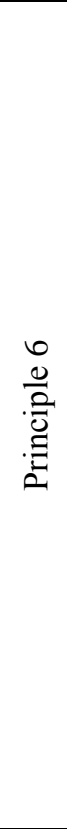 } & $\begin{array}{l}6.1 \text { Appropriate and principally correct statistical } \\
\text { processes such as computation, encoding, and } \\
\text { statistical analysis have been used to produce the } \\
\text { official statistics. }\end{array}$ & 0.7348 & 2.38 & 0.7399 & 2.58 & 0.7402 & 2.58 \\
\hline & $\begin{array}{l}6.2 \text { There are explanations or references concerning } \\
\text { the source, data acquisition and collection process. }\end{array}$ & 0.7794 & 2.52 & 0.7816 & 2.72 & 0.7789 & 2.71 \\
\hline & $\begin{array}{l}6.3 \text { The official statistics item is accurate and } \\
\text { trustworthy. }\end{array}$ & 0.6673 & 2.16 & 0.6731 & 2.35 & 0.6651 & 2.32 \\
\hline & $\begin{array}{l}6.4 \text { There were assessment and evaluation of the } \\
\text { method and process of official statistics production in } \\
\text { order to improve the process in the future. }\end{array}$ & 0.8088 & 2.62 & 0.8070 & 2.81 & 0.8112 & 2.82 \\
\hline & $\begin{array}{l}\text { 6.5 Rational and feasibility studies were conducted } \\
\text { on official statistics items. }\end{array}$ & 0.7048 & 2.28 & 0.6908 & 2.41 & 0.6962 & 2.42 \\
\hline & $\begin{array}{l}\text { 6.6 There are policies and/or clear procedure for } \\
\text { adjusting or amending the items to ensure the } \\
\text { provision of up-to-date and accurate data. }\end{array}$ & 0.7946 & 2.57 & 0.7931 & 2.76 & 0.8035 & 2.80 \\
\hline & $\begin{array}{l}6.7 \text { In case any error or deviation of official statistics } \\
\text { was found, there is immediate correction and } \\
\text { dissemination of information to Combination of data } \\
\text { the users. }\end{array}$ & 0.8043 & 2.60 & 0.8093 & 2.82 & 0.8109 & 2.82 \\
\hline \multirow{2}{*}{ 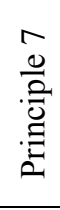 } & $\begin{array}{l}\text { 7.1 Provide service or dissemination of official } \\
\text { statistics regularly and in a timely manner. }\end{array}$ & 0.7322 & 2.37 & 0.7387 & 2.58 & 0.7324 & 2.55 \\
\hline & $\begin{array}{l}\text { 7.2 A follow-up process is in place to ensure that } \\
\text { necessary data for the production process is obtained } \\
\text { for the statistics to be produced in time. }\end{array}$ & 0.7757 & 2.51 & 0.7796 & 2.72 & 0.7802 & 2.72 \\
\hline $\begin{array}{l}\infty \\
\frac{0}{2} \\
\frac{0}{0} \\
\Xi \\
0\end{array}$ & $\begin{array}{l}8.1 \text { Official statistics are compared to data from other } \\
\text { sources and if there are differences, reasons are } \\
\text { clearly explained. }\end{array}$ & 0.7291 & 2.36 & 0.7362 & 2.57 & 0.7391 & 2.57 \\
\hline \multirow{5}{*}{ 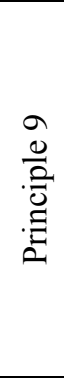 } & $\begin{array}{l}\text { 9.1 There is good management and storage with ease } \\
\text { of usage. }\end{array}$ & 0.7921 & 2.56 & 0.7945 & 2.77 & 0.7928 & 2.76 \\
\hline & $\begin{array}{l}9.2 \text { The official statistics produced are clear and } \\
\text { easily understood. }\end{array}$ & 0.7431 & 2.40 & 0.7524 & 2.62 & 0.7447 & 2.59 \\
\hline & 9.3 Provide quick and easy service to users & 0.7284 & 2.36 & 0.7418 & 2.59 & 0.7364 & 2.56 \\
\hline & $\begin{array}{l}\text { 9.4 A system to provide accurate and complete } \\
\text { metadata of official statistics is in place. }\end{array}$ & 0.7636 & 2.47 & 0.7634 & 2.66 & 0.7553 & 2.63 \\
\hline & $\begin{array}{l}9.5 \text { Complete and standardized metadata is readily } \\
\text { provided. }\end{array}$ & 0.8091 & 2.62 & 0.8063 & 2.81 & 0.8085 & 2.82 \\
\hline
\end{tabular}

\section{Recommendations for improvement of indicators.}

In order to evaluate quickly and easily the quality of the official statistic items that contain many indicators and to conform with the evaluative potential of the official statistics units in each branch, both in terms of personnel, tools and budget so that they become accurate and trustworthy to a certain level, where the data can be disseminated and used beneficially, the number of the indicators should be reduced. The model proposed is as follows:

Model 1: Include the first 20 general indicators of official statistics that are the most important has the most weighting and specific indicator groups. 
Model 2: Important indicators with weightings for indicators of high quality of official statistics

Model 3: Indicators that are important, with weighting for indicators of quite high quality of official statistics.

Model 4: Include the first 26 general indicators of official statistics that are the most important and/or has the most weighting and specific indicators groups that cover all 9 principles of the Code of Practice of quality management of the official statistics.

\section{Acknowledgements}

This study was made possible with funding from the National Statistics Office of Thailand. It was well done based on the project of "Development of Official Statistics and Statistical Information of Thai Government Office 21 Branches" which has Assistant Professor, Sorachai Phisalbutr, Ph.D. is as the team leader [5].

\section{References}

[1] The Expert Group on NQAF.(2012). Guidelines for the template for A Generic National Quality Assurance. N.P: n.p.

[2] European Statistical System Committee.(2011). EUROPEAN STATISTICS CODE OF PRACTICE. N.P: n.p.

[3] European Statistical System.(2012). Quality Assurance Framework of the European Statistical System. N.P: n.p.

[4] International Monetary Fund.(2003). Data Quality Assessment Framework (DQAF) for Monetary Statistics. Washington, DC, USA: International Monetary Fund.

[5] Phisalbutr, S., Mekbunditkul, T. and Kamdits, S.(2013). Development of Official Statistics and Statistical Information of Thai Government Office 21 Branches. Bangkok, Thailand: National Statistics Office. 